\title{
Redactioneel
}

\section{Nieuw jaar, nieuwe kansen}

2017 is een jaar vol verkiezingen. De Amerikanen, Nederlanders, Fransen en de Britten gingen al naar de stembus. De Duitsers volgen in september. Wat hebben we tot dusverre geleerd? Nou, bijvoorbeeld dat de 'boze burger' niet mag worden genegeerd. En dat dé waarheid niet bestaat (alternative facts!). Alles is perceptie. Hiermee samenhangend lijkt de allerbelangrijkste les toch wel dat autoriteit definitief niet langer vanzelfsprekend is. Automatische autoriteit bestaat niet meer. Gezag moet je doen. Dat geldt voor politici, maar ook voor de leraar, de dokter en de wetenschapper. En uiteraard ook voor de toezichthouder.

De hedendaagse westerse samenleving heeft een schizofrene relatie met het fenomeen autoriteit. Onze maatschappij is gestoeld op het uitgangspunt van individuele vrijheid. Hierdoor wordt elke vorm van autoriteit over het individu met wantrouwen bekeken. Tegelijkertijd is er het besef dat autoriteit nodig is. Wie waakt er anders over onze individuele vrijheid? Volgens de Hongaarse socioloog Frank Furedi is autoriteit een noodzakelijk kwaad zonder enige legitieme grond, dat zich alleen laat rechtvaardigen door de stelling dat het ontbreken ervan nog veel erger zou zijn. ${ }^{1}$ Ter bescherming van onze individuele vrijheden zijn we dan ook steeds meer van autoriteit gaan verwachten. Tegelijkertijd accepteren we steeds minder van haar. Het gevolg? Een permanente teleurstelling in het functioneren van autoriteit. En dus een verdere uitholling van haar legitimiteit. Ook toezichthouders hebben hiermee te maken.

Veel toezichthoudende organisaties noemen zichzelf 'autoriteit'. Denk alleen al aan de Autoriteit Financiële Markten, de Autoriteit Consument \& Markt, de Nederlandse Zorgautoriteit, de Autoriteit Persoonsgegevens en de Autoriteit Woningcorporaties. Autoriteiten. Maar hun gezag komt niet aanwaien. Er is werk aan de winkel. Dus wat kunnen autoriteiten of toezichthouders

1. F. Furedi, Authority - A sociological history, Cambridge: Cambridge University Press 2013. doen om hun gezag op te bouwen, te borgen of verder uit te breiden? Welke lessen zijn er te trekken?

Eerst maar eens: wat is autoriteit eigenlijk? De DuitsAmerikaanse filosofe Hannah Arendt onderscheidt autoriteit van macht. ${ }^{2}$ Macht is volgens haar altijd uitgesteld geweld. Macht komt voort uit een ongelijke relatie tussen twee entiteiten. Autoriteit, daarentegen, kent volgens haar een drieledige structuur: een eerste persoon onderwerpt zich op vrijwillige basis aan een tweede op grond van een door hen gezamenlijk erkende derde. Die derde factor was eeuwenlang het patriarchaat. Dat is nu verdwenen. Autoriteit heeft niet langer een inherente rechtvaardigheid. De rechtvaardiging voor autoriteit in onze hedendaagse samenleving is zuiver instrumenteel: we accepteren autoriteit alleen als het ons welzijn bevordert. $^{3}$

In dit licht is het dus logisch dat toezichthouders steeds meer oog hebben voor transparantie en het afleggen van verantwoording. Want wat levert al dat toezicht eigenlijk op? Welke effecten worden bereikt? Hoe draagt het toezicht bij aan de bevordering van ons welzijn? Toezichthouders zullen deze vragen overtuigend moeten kunnen beantwoorden om hun bestaan te rechtvaardigen en gezag te bekrachtigen. Maar er is meer. Vandaag de dag lijkt gezag ook op andere manieren te kunnen worden opgebouwd.

Aanknopingspunten hiervoor kunnen we vinden in de oratie van hoogleraar Burgerschap en Humanisering van de Publieke Sector, Evelien Tonkens. ${ }^{4}$ Tonkens onderscheidt vijf vormen van gezag. Klassiek zijn traditioneel, expertocratisch en bureaucratisch gezag. Van recentere datum zijn het populistisch en het dialogisch gezag, twee meer communicatieve vormen van gezag. Populistisch gezag is volgens Tonkens gebaseerd op persoonlij-

2. H. Arendt, 'What Is Authority?', http://la.utexas.edu/users/hcleaver/ 330T/350kPEEArendtWhatlsAuthorityTable.pdf. Geraadpleegd 7 juli 2017.

3. Furedi 2013

4. E. Tonkens, Roeping, gezag en loyaliteit. De publieke sector na het neoliberalisme, Utrecht: Universiteit voor Humanistiek 2016. 
ke identificatie van gezagsdragers met degenen over wie zij gezag uitoefenen. Gezagsdragers staan niet langer boven, maar naast burgers. Gezag door de belofte van nabijheid, aldus Tonkens. Dialogisch gezag is gebaseerd op persoonlijk begrip, betrokkenheid en goede communicatie. In het kader van dialogisch gezag moeten autoriteiten goed kunnen communiceren, luisteren en begrip tonen.

Gezag moet tegenwoordig dus worden 'verdiend' en communicatie lijkt hierbij de sleutel. Wat kan het toezicht met deze inzichten? De uitdaging is groot, maar de eerste stappen lijken al te worden gezet. Zo wordt de burger steeds vaker en nauwer bij het toezicht betrokken. Hij staat dan ook centraal in allerlei toezichtsvisies, -missies en -strategieën. Er zijn burger- en consumentenpanels. Er is steeds meer aandacht voor het informeren en empomeren van burgers en consumenten. Burgers en consumenten worden ingezet als mystery guests. Kortom, er wordt steeds explicieter voor, met en door burgers toezicht gehouden. Het toezicht lijkt steeds deliberatiever te worden.

Door zich nog meer te richten op burgers werken toezichthouders aan hun maatschappelijke legitimiteit. De burger is de klant en de klant is het hoogste gezag: toezichthouders moeten de burger dienen. Maar de toenemende focus op burgers en consumenten werpt ook nieuwe vragen op. Want wie is 'de burger' of 'de consument'? Is 'het volk' bij nadere studie niet een diffuse verzameling van individuen met tegenstrijdige standpunten? Naar wie luisteren toezichthouders dan? Wiens/wier welzijn bevorderen zij eigenlijk? En gaat dat niet ten koste van het welzijn van anderen? Kortom, de zoektocht naar gezag duurt voort.

Deze zoektocht is overigens niet alleen voorbehouden aan politici, wetenschappers en toezichthouders. Ook het Tijdschrift voor Toezicht zoekt mee. De afgelopen maanden hebben wij nog eens grondig gekeken naar het verleden, het heden en de toekomst van het tijdschrift. Het resultaat is een enigszins gewijzigde koers. Dit dubbelnummer verzorgt hiervan de aftrap. Zo is het omslag anders. Hierbij is gekozen voor de kleuren blauw en oranje. Oranje staat voor enthousiasme en activeert mensen. Dit om u als lezer te stimuleren om grondige, maar ook prikkelende en uitdagende bijdragen te blijven leveren aan het tijdschrift. En de kleur blauw? Blauw wordt geassocieerd met waarden als betrouwbaarheid, verantwoordelijkheid en veiligheid. Oftewel, met autoriteit.

Het jasje is dus nieuw. De inhoud is echter het belangrijkst. Ook qua inhoud hebben we een aantal veranderingen doorgevoerd. De basis blijft echter ongewijzigd. Het Tijdschrift voor Toezicht is en blijft een wetenschappelijk tijdschrift van, voor en door experts die zich beroepshalve bezighouden met het toezicht in al zijn facetten. Het tijdschrift blijft relevante kennis en informatie bundelen, duiden en verspreiden en daarmee een brug slaan tussen wetenschap en toezichtspraktijk.

Wat verandert er dan wel? De belangrijkste verandering is dat auteurs nog meer regie toekomt. Zij bepalen zelf tot welke rubriek hun bijdrage behoort. Een auteur geeft dus bijvoorbeeld zelf aan of zijn artikel door peers wordt gereviewd. Of dat zijn bijdrage als een 'uit het veld' moet worden beschouwd. Maar grote gevolgen voor de inhoud hebben deze wijzigingen niet; het Tijdschrift voor Toezicht blijft op zoek naar kwalitatief sterke bijdragen die relevant zijn voor de toezichtspraktijk. Ook de bijdragen aan dit dubbelnummer illustreren dit weer.

Lachnit richt zich in haar bijdrage op de rol van alternatieve handhaving in het mededingingstoezicht. Zij beschrijft hoe de Nederlandse Autoriteit Consument \& Markt, de Britse Competition and Markets Authority en de Franse Autorité de la Concurrence gebruikmaken van alternatieve handhavingsinstrumenten. Daarbij focust zij zich op de relatie tussen de gebruikte instrumenten, de onderliggende strategieën en de aard en achtergrond van de verschillende toezichthouders. Lachnits aanbevelingen zijn ook relevant voor alternatieve handhaving buiten het mededingingstoezicht.

Een 'alternatieve' vorm van handhaving is waarschuwen. Sinds 2012 maakt de AFM bijvoorbeeld gebruik van de melding 'Let op! U belegt buiten AFM-toezicht. Geen vergunning-en prospectusplicht voor deze activiteit'. Middels een gerandomiseerd experiment onderzochten Zijlstra en Van Egmond-de Boer de effectiviteit van deze 'wildwestwaarschuwing'. Met hun onderzoek illustreren zij het belang van effectmetingen in het toezicht. Een ander onderwerp dat al vaker in Tijdschrift voor Toezicht aan bod is gekomen, betreft de samenwerking tussen toezichthouders en inspectiediensten. In hun bijdrage onderzoeken Versluis en Polak de betrokkenheid van internationale netwerken en agentschappen bij de implementatie van Europese regelgeving op nationaal niveau. Op basis van twee studies - een analyse van de effectiviteit van internationale netwerken en een analyse van de rol van het Europese Spoorwegbureau bij het stimuleren van de implementatie van EU-spoorwegregelgeving - laten zij zien dat samenwerking gebaat is bij wederzijdse afhankelijkheid en informaliteit.

Huizinga en De Bree vragen onze aandacht voor het fenomeen 'doelverschuiving'. Dit definiëren zij als het ontstaan van een discrepantie tussen wettelijk of anderszins vastgelegde of overeengekomen doelen en de feitelijk nagestreefde doelen. In hun conceptuele artikel verkennen Huizinga en De Bree in welke mate en op welke wijze doelverschuiving binnen toezichthoudende organisaties voorkomt. Daarbij onderscheiden zij drie typen doelverschuiving: doelverplaatsing, doelversmalling en doelverbreding.

In de notenkraker gaat Nuijten aan de hand van een uitspraak van de Rechtbank Rotterdam in op een onderwerp dat recent ook al in Tijdschrift voor Toezicht aan bod kwam: mogen toezichthouders informatie vorderen en dwangsommen opleggen en vorderen van (rechts)personen die buiten Nederland gevestigd zijn? Dat dit onderwerp in korte tijd voor de tweede keer wordt besproken, is niet vreemd. Het toezicht wordt internationaler en toezichthouders krijgen steeds vaker met buitenlandse partijen te maken die in Nederland 
producten en diensten aanbieden. In relatief korte tijd zijn er volgens Nuijten dan ook zes rechterlijke uitspraken verschenen die over het 'territorialiteitsbeginsel' gaan. En daar zal het vermoedelijk niet bij blijven.

Tot slot, twee boekbesprekingen. In hun 'alternatieve recensie' gaan Postma, Grit en Stoopendaal in op het in 2016 verschenen boek Het huis van Argus - De wakende blik in de democratie van Huub Dijstelbloem. Dit boek bevat belangrijke aangrijpingspunten voor het doordenken van toezichtsontwikkelingen, in het bijzonder voor het betrekken van burgers bij het toezicht (mystery guests, burger-inspecteurs, etc.).

Mertens staat stil bij het recente werk Toezicht als beroep van voormalig AFM-bestuurder Theodor Kockelkoren. Daarbij gaat Mertens vooral in op het onderscheid dat Kockelkoren maakt tussen de idealistische en de nietidealistische toezichthouder. Mertens belangrijkste conclusie? Het toezicht is een domein voor nuchtere probleemoplossers.

Tot slot vragen wij uw aandacht voor de in dit nummer opgenomen Call for Papers. Tijdschrift voor Toezicht wil een brug blijven slaan tussen wetenschap en praktijk. De redactie nodigt $\mathrm{u}$ derhalve van harte uit om bij te dragen aan Tijdschrift voor Toezicht. 